\title{
Who Holds the Employment Contract 'Trump Card'? Comparing Labor Laws in Germany and the United States for the International Investor
}

\author{
by Carol D. Rasnic*
}

\section{INTRODUCTION}

The incremental numbers of German companies investing in American businesses as well as American enterprises undertaking operations in Germany pose mutual demands for a manageable knowledge of the new situs' commercial laws. Perhaps no component of a successful business is more basic than is the relationship between the company and its employees, making an understanding of the applicable labor laws critical.

German investments in American businesses continue to show a near geometric growth, having surged from Deutsche Mark (DM) 5 billion in 1976 to some DM 39 billion less than 10 years later. ${ }^{1}$ The primary reason usually cited is the mounting cost of doing business in Germany, a nation which has not only the highest corporate tax rates in the world ${ }^{2}$ but also the highest average wage of any major country. ${ }^{3}$

Despite these foreboding statistics, American businesses can also be expected to increase investments in Germany, due to the privatization of companies in former East Germany. The reunification treaty between the Bundesrepublik Deutschland (West Germany, or BRD) and the Deutsche Demokratische Republik (East Germany, or DDR) ${ }^{4}$ included

* Associate Professor of Labor Law, Virginia Commonwealth University. The author is grateful to Prof. Dr. Reinhard Zimmerman and Frau Gabriela Schmitt, Universität Regensburg, Germany, for their assistance in providing resource materials for this article.

1. Walter Treumann et al., U.S. Amerikanisches Wirtschaftsrecht 6 (2d. ed. 1990).

2. Seeking Lower Cosis, Germans Moving Plants to U.S., Richmond Times-DisPATch, May 26, 1992, at A-8, col. 1-4.

3. The average hourly pay and benefits for the German worker in 1991 translated into a U.S. dollar value of $\$ 25.14$, compared with $\$ 15.88$ for the average U.S. worker. (Note: This amount does not include workers in the former Deutsche Demokratische Republik, or East Germany, where the average wage at that time was roughly $2 / 3$ that of the worker in West Germany.) Frederick Kempe, Germany's Huge Bill for Bailing Out East is Riling its Workets, Wall Street Journal, May 15, 1992, at A-1, col. 6 .

4. Vertrag zwischen der Bundesrepublik Deutschland und der Deutschen De- 
the implementation of plans to convert from non-public ownership the businesses formerly the property of the now defunct communist government. The agreement created the Treuhand, a governmental entity charged with selling to private purchasers the former DDR's more than 12,000 companies (with some 4 million employees). ${ }^{5}$ As the temporary owner and business manager, the Treuhand applies a three-prong test in its choice of which bidders might purchase these properties: (1) amount of the proferred price, (2) guarantee from the purchaser of continued investment in the former DDR-owned enterprise for at least 5-6 years, and (3) commitment from the purchaser to provide jobs during the same period. Over 600 non-German investors have already bought such companies from the Treuhand, and many American businesses likely will share in this limited opportunity. ${ }^{6}$

This Article will summarize for those seeking to undertake such a trans-Atlantic venture in either direction the more striking of the differences between the labor and employment laws of Germany and the United States. Part II compares those laws characterized as "labor laws," i.e., governmental regulations applicable to units such as unions or other collective bodies of workers, and laws which apply to all workers, without regard to any distinguishing characteristics. Part III discusses laws referred to as "employment laws," i.e., those regulations designed to protect the rights of individual workers. The latter focuses largely on laws prohibiting discrimination in employment by reason of a worker's status.

\section{LABOR LAWS}

\section{A. Labor Unions and Management: The Collective Bargaining Agreement}

\section{United States}

Since 1935, workers in the United States have had the right under federal law to choose a bargaining representative. ${ }^{7}$ The Wagner Act

mokratishen Republik über die Herstellung der Einheit Deutschlands (Einigungsvertrag), August 31, 1990, 1990 Bundesgesetzblatt (BGBI.) II S. 889.

5. Ulrike Grünrock, representing the Treuhand Anstalt, Address at the Fulbright Commission Seminar, Berlin, (Mar. 30, 1993).

6. Id.

7. The original statute, the Wagner Act, was considerably augmented and amended in 1947, and is usually referred to by its latter popular name, the TaftHartley Act, Ch. 120, 61 Stat. 136 (1947) (codified as amended in scattered sections of 29 U.S.C.). 
(now Taft-Hartley Act) created the National Labor Relations Board (NLRB), a federal body authorized to determine the appropriate unit for bargaining purposes. ${ }^{8}$ A majority of that unit might then choose to be represented by a union. ${ }^{9}$

Thirty percent of the workers in the bargaining unit must evince a desire that the NLRB conduct a union election before it will do so. ${ }^{10}$ However, the statute does not require that the method of indicating the majority choice be an election, only that there be clear evidence of more than $50 \%$ support. The U.S. Supreme Court has acknowledged, however, that the election manner is both the "most commonly traveled route" and the "preferred route." 11 This majority-choice rule makes the union the exclusive representative, ${ }^{12}$ so that there is no possibility of more than one union within a single unit.

The right of labor in the United States to strike an employer over a labor dispute is implicit in the statutory right to engage in "concerted activities for the purpose of collective bargaining or other mutual aid or protection."13 This statutory right can be bargained away by the union if arbitration has been accepted as an alternate form of dispute settlement. ${ }^{14}$ Moreover, even if the right to strike had been expressly waived by the union via a contractual no-strike clause, accepted in exchange for a provision palatable to it, such a waiver refers only to economic strikes (i.e., those relating to wages, hours, or terms and conditions of employment). The right to strike over an employer's commission of an unfair labor practice cannot be waived..$^{15}$

8. 29 U.S.C. 159 (b) (1988). There are minor restrictions on the NLRB's powers in this regard which are not germane to this discussion.

9. 29 U.S.C. 159 (a) (1988). The courts have interpreted this concept of "majority" to mean a majority of those workers who actually voted, provided the number of the voter turnout was substantial and representative. See NLRB v. Standard Lime \& Stone Co.; 149 F.2d 435 (4th Cir. 1945), where the federal appellate court affirmed the NLRB's certification of a union even though less than a majority of the workers in the unit had even voted.

10. 29 U.S.C. $159(\mathrm{c})(1)(1988)$. This $30 \%$ is usually obtained through signed authorization cards.

11. NLRB v. Gissel Packing Co., Inc., 395 U.S. 579 (1969). In Gissel, the Court approved certification of a union which had received less than a majority of votes cast. Such certification was held to be justified because of the union's showing that (1) a fair election was not possible because of the employer's pressure on its workers, and (2) the unambiguous language on the authorization cards signed by a substantial majority clearly proved support for the union.

12. 29 U.S.C. $\$ 159$ (a) (1988).

13. Id. at 157 .

14. Boys Markets, Inc. v. Retail Clerks Union, Local 770, 398 U.S. 235 (1970).

15. Mastro Plastics Corp. v. NLRB, 350 U.S. 270 (1956). 
The Taft-Hartley Act makes it an unlawful unfair labor practice for an employer to discriminate against an employee because of his union or non-union affiliation. ${ }^{16}$ Thus, the terms of a collective bargaining agreement between a union and an employer must apply to all employees in the unit, whether or not they are union members.

The typical collective bargaining agreement in the United States is between the union and a single employer, although there are indeed multi-employer bargaining groups. ${ }^{17}$ An example is the Major League Baseball Owners' Association, comprised of the 28 professional major league baseball teams, which executes a single contract with the union, the Major League Players' Association. Membership of an employer in such a group is entirely voluntary, and it is permitted liberal withdrawal rights. ${ }^{18}$

Finally, the Taft-Hartley Act requires an employer to bargain with a certified union ${ }^{19}$ with respect to wages, hours, and terms and conditions of employment. ${ }^{20}$ The union is under the same statutory duty to bargain with the employer. ${ }^{21}$

\section{Germany}

The labor union in Germany bears little resemblance to the foregoing paradigm. First, a significant majority of companies belong to large inter-industrial groups of employers. ${ }^{22}$ The largest is the Federal Association of German Employers (Bundesvereinigung der Deutschen Arbeitgeberverbände), or $\mathrm{BDA}$, to which $80 \%$ of all German employers belonged in $1991 .{ }^{23}$ The BDA itself is not permitted to be a party to a

16. 29 U.S.C. $158(a)(3)(1988)$.

17. See 48 Am. Jur. 2d Labor and Labor Relations 669 (1985).

18. See 51 C.J.S. Labor Relations $\$ 180$ (1967). One recent example was the withdrawal of Pittston Coal Corporation from the Bituminous Coal Operators' Association (BCOA), comprised of more than 100 coal companies. The result was the BCOA's execution of one contract and Pittston's execution of a separate one with the United Mine Workers Association (UMWA).

19. 29 U.S.C. $\$ 158(a)(5)(1988)$.

20. Id. $\$ 158$ (d).

21. Id. $\$ 158(\mathrm{~b})(3)$.

22. Manfred Weiss et al., The Settlement of Labour Disputes in the Federal Republic of Germany, in Industrial Conflict Resolution in Market Economies: A Study Of Australia, the Federal Republic of Germany, Italy, Japan, and the U.S. 93 (Tadashi Hanami and Roger Blanpain eds., 1984).

23. Wolfgang Zöllner und Karl-Georg Loritz, Arbeitsrecht 101 (9th ed. 1992). 
collective bargaining agreement, ${ }^{24}$ but its sheer size is indicative of its power and influence.

German companies also belong to geographic regional groups of employers, organized along industry lines. It should be noted that the concept of "industry" in this context is quite an expansive one. To illustrate, the "metal industry" includes automobile, electric, shipbuilding, and machine-building companies, among others. ${ }^{25}$ This regional group is the actual employer party to the collective bargaining agreement, and the contract is with all members of the union for that industry in the region. The boundaries for the region are negotiated by the union and the employers, and the several contracts for the various regions in the same industry do not usually vary substantially among the regions. ${ }^{26}$

Unions usually are not organized according to the workers' craft or skill, but rather along industrial lines. ${ }^{27}$ The typical union in Germany is an enormous body, and Germany's IG Metall (Industrie-GewerkschaftMetall) is the world's largest, with some 3.6 million members. ${ }^{28}$ In turn, most unions belong to a comprehensive association of unions, the German Labor Union Federation (Deutscher Gewerkschaftsbund), or DGB. This body consisted of 9.46 million members at the end of 1989. ${ }^{29}$ As with the BDA, the DGB is not a party to the collective bargaining agreement, which is executed between the industrial union (representing all members in the geographical region) and the regional employer group for that industry. Indeed, it is lawful for a single employer to contract with a union,,$^{30}$ but because of the prevalence of

24. Richard Richardi, Kommentar zum bürgerlichen Gesetzbuch mit Einfährungsgesetz und Naben gesetzen, in Recht Der Schuldverhältnisse, 1 611-15 (Julius von Staudinger ed., 12th ed. 1957).

25. Manfred Weiss, The Role of Neutrals in the Resolution of Interest Disputes in the Federal Republic of Germany, 10 CoMp. LAB. L.J. 339 (1988).

26. Id. at 340 .

27. Franz-Jürgen Säcker, The German Model of Codetermination: Perspectives, Confrontative Issues, and Prospective Developments, in Management Under Differing Value Systems 319 (Günther Dugor et al. eds., 1981).

28. Germans' Reactions to Strike Settlement Mixed, Richmond Times-Dispatch, May 9, 1992, at A-5, col. 2-6.

29. Zöllner UND LORITz, supra note 23 , at 99 . This refers only to workers in what was West Germany prior to reunification.

30. Richardi, supra note 24 , at 9938 . Such a contract between a union and a single employer is called a "Firmenvertrag" (company collective bargaining), and a contract with the regional employer group is called a "Verbandstarifvertrag" (association collective bargaining agreement). Id. 
employer memberships in a regional group, these single employer contracts are the exceptions rather than the rule.

The Federal Law on Collective Bargaining ${ }^{31}$ regulates union-management contracts. Unlike the statutory duty to bargain under TaftHartley, there is no such duty on either union or employer under German law. ${ }^{32}$ Further, there is not the same rule limiting one bargaining agent to a unit. German law requires only that a union have the support of enough employees to exhibit sufficient "soziale Mächtigkeit," or social power. ${ }^{33}$ The law does not define union (Gewerkschaft), but merely simplistically states that it is one of the two parties to a collective bargaining agreement. ${ }^{34}$

German law implies that the union has committed itself not to strike during the unexpired term of a collective bargaining agreement over any item which is covered in the contract. Referred to as "Friedenspflicht," or duty to keep the peace, this obligation is not negotiable. ${ }^{35}$

A final distinction in this area of German law relates to the worker's right to representation by the union. The German Constitution (Grundgesetz) expressly protects workers' freedom of association. ${ }^{36}$ The federal labor court has interpreted this right to include the freedom not to associate,$^{37}$ a concept similar to Taft-Hartley's protection of a worker's right to join a union and the right also to refrain from union membership. ${ }^{38}$ However, while the collective bargaining agreement in Germany cannot expressly exclude non-union members from its provisions, ${ }^{39}$ the law does allow the employer unilaterally to refuse to grant to nonunion employees those benefits contracted for by the union. ${ }^{40}$

31. Tarifvertragsgesetz (TVG), 1969 BGBI.I S. 1323.

32. Manfred Weiss, Federal Republic of Germany, in 5 International Encyclopaedia For Labour Law and Industrial Relations 128 (Roger Blanpain ed., 1986) [hereinafter "INTERnational Encyclopaedia"].

33. Decision of the Federal Labor Court, Bundesarbeitsgericht (BAG) AP Nr. $25 \mathrm{zu} \subseteq 2$ TVG.

34. TVG $\$ 2$.

35. Zöllner und LoRITz, supra note 23, at 351 .

36. Grundgesetz (GG) art. 9(3).

37. BAG, 1987 Der Betrieb 2312.

38. 29 U.S.C. 157 (1988).

39. Wolfgang Däubler, The Individual and the Collective: No Problem for German Labor Law?, 10 Comp. LAB. L.J. 505, 511 (1988). Professor Däubler calls this a "remarkable consequence" that the union member must pay for his positive freedom of association. (He estimates that dues constitute about $1 \%$ of the worker's monthly income). However, one who exercises his negative freedom and does not pay for the privilege may not even be contractually "burdened with the loss of a vacation bonus."

40. TVG $\$ 3,91$. 
A hypothetical might illustrate these differences. Assume a tire manufacturing company in a small city has 75 employees, including blue-collar clerical workers and laborers. If the company were in the United States, the NLRB might decide that all 75 workers appropriately belong in the same bargaining unit. By signing authorization cards, 23 of those $(30 \%)$ might initiate an election, the union petitioning the NLRB being on the ballot. Further assume that 60 of the 75 workers vote when the election is held. If at least 31 , a majority, vote for the union, it will be certified as the bargaining representative for all 75 (including those who did not vote, and those who voted against the union). It is the statutory duty of both employer and union to bargain, and any resulting collective bargaining agreement covers all 75 workers. Any subsequent right to strike in the event of a labor dispute is implied, absent a no-strike clause in the contract. Even if such a provision is included, the workers nonetheless might strike in response to the employer's unfair labor practice.

The same company in Germany would be regarded as being in the metal industry (as part of the automobile industry), and as such would likely belong to the regional group of employers in that industry. Those of its employees who have joined a union will be members of IG Metall. The union contract binding upon these parties is between all employers in this regional group and the IG Metall regional branch. Neither the employer group nor the union is obligated by law to bargain. Once a collective bargaining agreement has been executed, however, there is no right to strike until it has expired. Also, it is clearly within the employer's rights to pay wages and grant benefits guaranteed in the contract only to those employees who are members of IG Metall.

\section{B. Works Councils and Employee Codetermination in Germany}

Two potent statutory rights of workers in Germany have no parallels in American law, and any enterprise contemplating doing business in Germany should be familiar with these principles.

\section{Works Council (Betriebsrat)}

Since the Work Councils Act (Betriebsverfassungsgesetz) ${ }^{41}$ was passed by the German parliament (Bundestag) in 1952, all businesses with at least five employees are technically required to establish a works council

41. Betriebsverfassungsgesetz (BetrVG), 1988 BGBI. I S. 2261. 
of elected representatives from labor. ${ }^{42}$ There is no correlation between union membership and works council membership, and many works council members concurrently belong to a union. ${ }^{43}$

This body must be consulted by the employer prior to implementation of most significant decisions routinely considered in the United States as entirely within management's discretion. These include hiring or transferring an employee, ${ }^{44}$ terminating or extraordinarily discharging (i.e., immediately discharging without notice), ${ }^{45}$ and drafting of general work place rules. The latter encompasses 12 specific subject matters, including time, place and manner of payment of wages; work accident rules; amount of wages and other performance-related compensation; and hours of work. ${ }^{46}$

The employer's agreement with the works council regarding work rules (which, unlike the German collective bargaining agreement with a union, might be unwritten $)^{47}$ is comparable to the union-management collective bargaining agreement in the United States. While the employer might exclude non-union members from the collective bargaining agreement coverage, an individual employee is never allowed to disassociate from the works council. ${ }^{48}$ The most striking distinction is that, regardless of the size of a company, as few as five employees can demand compliance with the works council law, whereas a majority of workers must choose a union as their representative under American law. Also, unlike the American collective bargaining agreement, the German statute does not allow employees to strike an employer in order to attain a works council-company agreement. ${ }^{49}$

In reality, not all German companies subject to the law have works councils. ${ }^{50}$ Nonetheless, it is logical to assume that the potential of having to deal with such a body if employees so desire prompts many businesses to deal more favorably with labor.

42. BetrVG $\$ 1$. The number of employees on the works council ranges from 1 to 31 , increasing with the number of total employees. $I d$. $\$ 9$.

43. International Labour Office, Geneva, Switzerland, Workers' Participation In Decisions Within Undertakings 85, 137-38 (1981).

44. BetrVG \$99.

45. Id. 102 .

46. Id. $\ 87$.

47. TVG $1(2)$ requires collective bargaining agreements to be written.

48. Däubler, supra note 39 , at 513-14.

49. BetrVG $₫ 76$.

50. One German labor law authority has written that the general rule is that only those employers with more than 50 employees have works councils. Manfred Weiss, Federal Republic of Germany, 9 CoMp. LAB. L.J. 82, 83 (1987). 


\section{Employee Codetermination (Mitbestimmung)}

Larger businesses-i.e., those with more than 2,000 workers-are required by statute to allow workers to assist in determining management policy. The 1976 Codetermination Act (Mitbestimmungesetz) ${ }^{51}$ provides for $50 \%$ of the corporate supervisory board (Aufsichtsrat) to be represented by labor.

The German corporation has not only a board of management (Vorstand), which corresponds to the board of directors in an American corporation, but also a supervisory board consisting of an equal number of employees and shareholders. ${ }^{52}$ Although the supervisory board has no management functions ${ }^{53}$ (the board of management actually directs and operates the company),${ }^{54}$ the supervisory board appoints members of the board of management. The latter board must report regularly to the supervisory board regarding all corporate affairs. ${ }^{55}$

The supervisory board has one vote per member, ${ }^{56}$ so that a shareholder member does not gain power as his number of shares owned increases. This equates the voice of the $50 \%$ employee contingent on the board to that of all shareholder owners collectively, so that there results a true balance of power.

For the mining and iron and steel industries, workers are given some direct control in policy decisions. Since 1951, German federal law has provided for employee members on the board of management of companies in these industries with 1000 or more workers. ${ }^{57}$ This is the one situation under German law in which there is an assurance of employee participation in actual management.

\section{Wage and Hour Laws}

\section{United States}

Since 1938, the United States has had a federal minimum wage law. ${ }^{58}$ This statute, the Fair Labor Standards Act, was substantively

51. Mitbestimmungsgesetz (MitbG), 1976 BGB1. I S. 1153.

52. Aktiengesetz (AktG), 76(3), 84, 1965 BGBl. I S. 1089.

53. Id. $\$ 111 \uparrow 4$.

54. Id. $\$ 76$.

55. Id. $\$ 90$.

56. MitbG $\$ 27$.

57. Gesetz über die paritätische Mitbestimmung der Arbeitnehmer in Bergbauunternehmungen des Eisen und Stahlindustrie-Montanmitbestimmungsgesetz (MontanMitbG), 1951 BGB1. I S. 347.

58. The Fair Labor Standards Act, 29 U.S.C. $\$ 206$ (1989), originally established 
amended in 1963 by passage of the Equal Pay Act, ${ }^{59}$ which requires equal pay for equal work between the sexes.

The same statute contains the so-called maximum hour law. It does not limit the number of hours an employee might work, but it requires one and one-half times the average hourly pay for those hours in excess of 40 per week. ${ }^{60}$ Exempt from both the minimum wage and maximum hour provisions are workers who meet the statutory and regulatory definitions of executive, administrative, professional, and outside sales employees. ${ }^{61}$ The effect of this exemption is to permit management's requiring these persons to work overtime without additional compensation.

For the most part, Congress has not addressed vacations and miscellaneous days off. One exception is the recently enacted Family and Medical Leave Act which allows employees to take up to 12 weeks of unpaid leave in the event of birth or adoption of a child; need to care for a seriously ill spouse, parent, son or daughter; or hardship imposed by the employee's own illness. ${ }^{62}$

\section{Germany}

Germany has no minimum wage laws, either at the federal or state (Land) levels. ${ }^{63}$ Because of the widespread applicability of collective bargaining and works council agreements, however, German workers have no need for any statutory minimum. The German worker works fewer hours and has longer vacations and more holiday and sick leave-yet has higher wages-than does the worker in any other industrial country. ${ }^{64}$

the minimum hourly rate of pay for covered employees at 25 cents. There have been periodic increases by amendment to the law, the most recent setting the minimum wage at $\$ 4.25$ per hour, effective April 1, 1991. 29 U.S.C. 206 (1989), Pub. L. 101-157, 2, 4(b), and Pub. L. 101-239, Title X; 10208(d)(2)(B)(i), 103 Stat. 2481.

59. 29 U.S.C. $\$ 206(d)(1)$ (1963). See infra, notes 137-140 and accompanying text on Equal Pay Act.

60. 29 U.S.C. $\$ 207$ (1988).

61. Id. $213(\mathrm{a})(1)$.

62. Family and Medical Leave Act, Public Law 103-3, codified at 29 U.S.C. 2601 et seq. (1993). This law covers all employers with at least 50 employees during each work day in at least 20 calendar weeks in the current or preceding year. Eligible employees are those who have worked for the employer for at least 12 months and for at least 1,250 hours during the preceding 12 months.

63. Peter Hanau and Klaus Adomeit, Arbeitsrecht 17 (9th ed. 1988).

64. John Dornberg, German Strikers Mark End of Business as Usual, Richmond Times-Dispatch, May 24, 1992, at F-3, col. 1-6. 
With respect to maximum hours, federal law specifies the usual workday as 8 hours. ${ }^{65}$ German law distinguishes between "Mehrarbeit" ("more" work), which refers to work in excess of this statutory 8hours, and "Uberstunden" ("over" hours), which refers to work in addition to what is typical for that particular work establishment. The latter is established in the collective bargaining or works council agreement, ${ }^{66}$ but the law requires additional pay for Mehrarbeit. This additional compensation (unless otherwise in the collective bargaining or works council agreement) is at least $25 \%$ more than the regular rate of pay ${ }^{67}$ German law also requires regular work pauses of $1 / 2$ hour (or two 15-minute breaks) after 6 hours of work for male workers. ${ }^{68}$

Federal law also sets a minimum paid time off for vacation, or "Urlaub," 69 as 18 work days, or nearly four weeks for one who works a 5-day week. Because of the prevalence of collective bargaining and works council agreements, the average German worker in 1983 actually enjoyed an average of 36 days-or an excess of seven weeks-paid vacation days per year. ${ }^{70}$

Two laws secure additional days off, one which mandates time off for Sundays and legal holidays, with stated exceptions. ${ }^{71}$ A number of the legal holidays in Germany are Catholic holidays, some of which are mandatory even in predominately Protestant regions. The Land of Bavaria (Bayern) enjoys the greatest number, at 14 per year. All Länder, however, have no fewer than ten such annual holidays. ${ }^{72}$ The second statute compounds these provisions from the employer's perspective, generally mandating official closing times and days for most establishments. ${ }^{73}$

Germany has long had a liberal parental leave statute. Although the original law granted leave to the mother, since 1985 either parent

65. Arbeitszeitordnung (AZO) $₫ 3,1938$ Reichsgesetzblatt (RGBl.) I S. 447.

66. ZöLLNER UND LORITZ, supra note 23, at 169.

67. AZO $\$ 15(2)$.

68. Id. 12 abs. 2. The different rules for female and juvenile workers are discussed infra notes 159 and 114 respectively, and accompanying text.

69. Bundesurlaubsgesetz (BUrlG) $\ 3$ abs. 1, 1963 BGB1. I S. 2. Additional time is assured for juvenile (see infra note 113 and accompanying text) and disabled (see infra note 129 and accompanying text) workers.

70. INTERnational ENCYClOPAEDia, supta note 32, at 69.

71. Gewerbeordnung (GewO), 1987 BGB. I S. 425. Exceptions generally relate to the type of establishment such as hospitals, pharmacies, gasoline stations, public transportation offices, etc.

72. Arbeitsgesetze 82 (Reinhard Richardi ed., 41 st ed. 1991).

73. Gesetz über Ladenschlub (LadschlG), 1956 BGB. I S. 875. There are similar exceptions as in the GewO. LadschlG \$ 4-10. 
might take advantage of the permitted 18 months leave from work, with the job secure upon his or her return. Although the leave is not officially with pay, the federal government pays the employee DM 600 per month. ${ }^{74}$

A summary of the wage and hour laws shows that the U.S. statutes provide for minimum wages and $11 / 2$ times the usual rate of pay for work exceeding 40 hours per week. On the other hand, Germany assures workers liberal vacations, and Sundays and holidays off work. In this area of law, only the overtime pay, at $25 \%$ more than the usual rate rather than the $50 \%$ increase under U.S. law, is less advantageous to the German worker than to his American counterpart. Augmenting the benefits the German worker enjoys are hefty union and works council contracts, which have compensated for the absence of a minimum wage law in Germany.

\section{Employee Rights Regarding Termination}

\section{United States}

Perhaps no other rule of law in the United States has provided more fodder for law reviews and legal commentary in recent years than has the so-called "employment-at-will" rule. This principle, which has been applied in all state courts, is founded on a statement in an 1877 treatise generally accepted as having been presumptively made by the author without any justifying judicial authority. ${ }^{75}$ The employment-atwill rule states simply that an employment contract for an unspecified period is terminable at any time by either employer or employee, with or without cause.

The long-accepted exceptions which require an employer to have good cause for discharge are (l) contracts for a definite term, ${ }^{76}$ and (2) contracts in which the employee has given the employer something in

74. Bundeserziehungsgeldgesetz (BErzGG) $\$ 5$ abs. 1, 1989 BGBl. I S. 1550. After six months, this sum decreases. Id.

75. See, e.g., J. Peter Shapiro and James F. Tune, Implied Contract Rights to Job Security, 26 Stan. L. Rev. 335, 341-42 n. 54 (1974). The origin of the rule was Horace G. Wood, A Treatise on the Law of Master \& Servant $\$ 134$, at 272 (1877).

76. See, e.g., Rochester Capital Leasing Corp. v. McCracken, 295 N.E.2d 375 (Ind. 1973). Usually, employment designated as "permanent" or "lifetime" is presumed to be for an indefinite term and therefore terminable without cause. See Annotation, Modern Status of Rule that Employer May Discharge at-Will Employee for Any Reason, 12 A.L.R.4th 54 (1984). 
addition to the commitment to perform services. " In recent years, many. states have recognized additional exceptions, the two most recurring ones being the employee handbook exception and the "public policy" exception.

Based on breach of contract, many courts have held that handbooks or employment manuals given by employer to employee create binding commitments. If the manual contains a provision that the employee will be retained as long as his work is acceptable, for example, some courts have held that a termination is lawful only if the employer can show good cause. ${ }^{78}$ In addition to this substantive right, some states have held that the procedural steps such manuals specify prior to discharges also vest contractual rights in the employee and that these steps must be followed, whether or not good cause can be shown. ${ }^{79}$

The second exception is one based on tort concepts, making unlawful any termination when the employer's reason violated public policy. Some less proactive courts limit "public policy" to that which has been articulated through legislation..$^{80}$ More innovative courts less wedded to judicial restraint have created public policy beyond any directives from the legislature. ${ }^{81}$

It is not within the scope of this summary review to analyze exhaustively the exceptions to the employment-at-will rule. It is significant, however, that a draft uniform law which would require good cause for all terminations in businesses with five or more employees ${ }^{82}$ in those states where it is enacted has been assessed as having "poor prospects" for adoption. ${ }^{83}$ Further, a majority of jurisdictions continue to apply

77. See, e.g., Bondi v. Jewels by Edwan, Ltd., 73 Cal. Rptr. 494 (1968) (employee had sold his own business in response to the employer's hiring him upon that condition).

78. Generally recognized as the seminal case on this point is Toussaint v. Blue Cross, 292 N.W.2d 880 (Mich. 1980).

79. See, e.g., Woolley v. Hoffman-LaRoche, Inc., 491 A.2d 1257 (N.J. 1985).

80. See, e.g., Bowman v. State Bank of Keysville, 331 S.E.2d 797 (Va. 1985).

81. For example, in Wagenseller v. Scottsdale Memorial Hospital, 710 P.2d 1025, 1035 (Ariz. 1985), the Arizona Supreme Court did not view statutes and constitutions as being the sole embodiments of public policy, deeming the courts also capable of pronouncing what is in the public interest. Here, a nurse had been terminated allegedly for having refused to "moon" an audience of her colleagues at a hospital social function. The Court held such reason, if it were in fact the cause of her dismissal, to be clearly contrary to public policy, regardless of any specific state statute establishing such public interest. Id.

82. 1(2) Draft Uniform Employment Termination Act, August 2-9, 1991, in Lab. Rel. Rep. (BNA), Ind. Empl. Rts. Manual, at 540:21-540:41.

83. See Michael J. Phillips, Toward a Middle Way in the Polarized Debate Over Employment-at-Will, 30 AM. Bus. L.J. 441, 442 (1992). 
the rule that discharges need not be based on good cause if the employment is for an indefinite period. ${ }^{84}$

\section{Germany}

Under German law, any employee who has worked for an employer for at least six months may not be terminated without cause. ${ }^{85}$ The only three reasons constituting such cause are (1) economic concerns, independent from the employee, ${ }^{86}$ (2) personal characteristics of the employee which are beyond his control and which affect his work, ${ }^{87}$ and (3) the employee's inferior work or misconduct at work. ${ }^{88}$

The employer must notify the works council before it implements a decision to discharge ${ }^{89}$ and the council's one week to respond defers the termination at least for this period. ${ }^{90}$ Although the works council cannot actually prohibit the termination, ${ }^{91}$ it can object on any one of five objective reasons specified in the statute. ${ }^{92}$

In addition, workers are entitled to notice before a termination. German law distinguishes between white-collar workers (Angestellten), who usually are paid a salary (Gehalt) and perform mental and/or discretionary work, and blue-collar workers (Arbeiter), who usually are paid an hourly wage (Lohn) and perform manual labor. ${ }^{93}$ The statutes conflict as to required notice, guaranteeing white-collar workers no less than six weeks notice, ${ }^{94}$ and blue-collar workers only two weeks notice..$^{95}$

84. See Progress Printing Co., Inc. v. Nichols, 421 S.E.2d 428, 429 (Va. 1992).

85. Kündigungsschutzgesetz (KSchG) $\ 1,1969$ BGB1. I S. 1317.

86. Id. $\ 1$ abs. 3. This is referred to as "Betriebsbedingtkündigung," or "discharge because of workplace reasons." Even when an employer must layoff employees because of business difficulties, however, the statute requires that he consider their seniority, age, and number of dependents.

87. Id. $\ 1$ abs. 2. This is referred to as "Personenbedingtkündigung," e.g., the worker's inability to work because of his illness.

88. Id. This is referred to as "Verhälungsbedingtkündigung," or "discharge because of behavior." Discharge for this reason requires that the employer first warn the employee that he is being considered for termination and the reason(s) for such.

89. BetrVG 5 99(1).

90. Id. $\ 102$.

91. The employee discharged against the works council's recommendation must resort to an action against the former employer in a local labor court.

92. BetrVG $\subseteq 102$ abs. 3 .

93. Richardi, supra note 24 , at paragraph 334 .

94. Gesetz über die Fristen für die Kündigung von Angestellten, 1926 RGB1. I 399, ber. 412, geändert durch Gesetz vom Dez. 1989, BGB1. I S. 2261.

95. Bürgerliches Gesetzbuch (BGB) , 1896 RGBI. 195, zuletzt geändert 1990 BGBl. I S. 2002, 622 abs. 2. 
Because the German constitution assures equality before the law, ${ }^{96}$ a 1990 decision by the constitutional court held the disparity unconstitutional. ${ }^{97}$ The present status is that an employer may determine which of the two pre-termination statutory notices it will adopt and apply it objectively to white-collar and blue-collar workers alike.

Clearly, employers in Germany face obstacles to terminating an employee which companies in the United States do not. These notification laws and requirements for communication with works councils have become accepted ways of life to businesses in Germany.

\section{EMPLOYMENT LAWS}

For particular categories of workers, laws in both countries afford special privileges and protections, and, in some cases, more restrictions. These major categories are non-citizens; employees under the age of majority; disabled workers; and (in the case of Germany) female workers, especially pregnant workers.

\section{A. Aliens \\ 1. United States}

Beginning in 1986, Congress has attempted to control the entry of illegal aliens by eliminating the job opportunities which lure such persons into the country. The Immigration and Naturalization Control $\mathrm{Act}^{98}$ initiated the scheme of requiring employers to secure proof of employment eligibility from all new hires.

Such eligibility can be evidenced through a single document which both identifies the subject and shows that he or she has the right to work in the United States. Examples are a American passport; a foreign passport endorsed by the Attorney General as authorizing the holder to work; or a resident alien card issued through the Immigration and Naturalization Service (INS), commonly referred to as a "green card." In the alternative, the work applicant might prove identity with one document (such as a driver's license) and his or her right to work with a second (such as a Social Security card or a birth certificate showing American nationality).

The employer must record the information on a special government form (the I-9) and retain it for three years, or one year after termination

96. GG art. 3 .

97. Bundesverfassungsgericht (Federal Constitutional Court) (BVerfG) Entscheidung 82 S. $126=$ AP Nr. 28 zu $\$ 622$ BGB, May 30, 1990.

98. 8 U.S.C. 1324a (1986). 
of employment of the subject, whichever comes later. It is not required that the employer verify the authenticity of any documents, only that it act in good faith. Failure to comply with the paperwork requirements can result in a civil penalty of $\$ 100-1000$ per person..$^{99}$ If the employer has been guilty of actually hiring an illegal alien, the civil penalty is $\$ 250-2,000$ for a first offense, $\$ 2,000-5,000$ for the second, and $\$ 3,000$ 10,000 for third and subsequent ones. ${ }^{100}$ If the government proves a "pattern or practice" of violations, there is a potential criminal penalty of $\$ 3,000-10,000$ fine and/or six months imprisonment. ${ }^{101}$

\section{Germany}

Non-citizen employees in Germany might be categorized in 3 classifications: (1) political refugees, (2) citizens of other European Community countries, and (3) all others.

The German constitution assures asylum to any one persecuted because of political reasons. ${ }^{102}$ This has resulted in a veritable deluge of immigrants: some 368,000 political refugees from war-torn Eastern Europe and parts of Africa and the Middle East sought sanctuary in Germany in 1992, and during only the first three months of 1993, the figure was $330,000 .{ }^{103}$ These non-citizens must have a means of support, so not only are they entitled to the many social provisions German law provides, but they also might obtain gainful employment where there are opportunities. The violence resulting from resentment over these "Ausländer," or non-Germans, merits comment. During February, 1993, there were some 429 manifestations of hostility against Ausländer throughout Germany, ${ }^{104}$ often because of bitterness over jobs presumed usurped from Germans in a time of climbing unemployment. ${ }^{105}$ Apparently a small minority of Germans are privy to such attacks, and frequent counterdemonstrations are regular events through-

99. 8 U.S.C. $1324 a(\mathrm{e})(5)(1988)$.

100. Id. $\$ 1324 \mathrm{a}(\mathrm{e})(4)(\mathrm{A})$.

101. Id. $\$ 1324 \mathrm{a}(\mathrm{f})(1)$.

102. GG art. 16(2) (1988).

103. Craig Whitney, New York Times Bonn correspondent, addressing Fulbright Commission seminar, March 27, 1993, Berlin.

104. This figure reflects 18 arsons, 56 assault and batteries, and 355 miscellaneous attacks, such as misdemeanor thefts, verbal insults, and damage to property. BerLinER Morgenpost, April 2, 1993, at 1, col. 6.

105. About 4 million people in all of Germany are presently unemployed. The official rate is approximately $7 \%$ in the BRD, but $14 \%$ in the former DDR. Whitney, supra note 103. 
out the country. Nonetheless, the reality of such tortious and criminal activity is a fact which might be considered by the American business contemplating a business venture in Germany.

Secondly, Germany and the other member nations of the European Community ${ }^{106}$ are parties to a treaty assuring "Freizügigkeit," or freedom of movement and privileges afforded citizens. ${ }^{107}$ Thus, any national of another European Community is eligible to work in Germany.

Others might have indirect rights by virtue of conflict of law principles. For example, the employment contract of an American employee of a multinational concern who has worked a number years in London immediately prior to his or her transfer to a German branch would be governed logically by the law of Great Britain. ${ }^{108}$ As such, he might be entitled to the European Community privilege of employment eligibility. The non-German who is neither a political refugee or a national of a European Community country, however, is subject to much the same work visa and work permit (Arbeitserlaubnis) requirements as are all aliens in the United States. ${ }^{109}$

\section{B. Working Minors}

The two countries' laws with respect to employees under the age of 18 are strikingly similar. For example, both the United States' Fair Labors Standards Act child labor provisions ${ }^{110}$ and Germany's Jugendarbeitsschutzgesetz ${ }^{111}$ restrict work for minors with remaining school obligations under applicable state or Land law. Both except from prohibited work employment such as newspaper deliveries and acting or performing on television, in motion pictures or on stage. Both deal separately with agricultural work or work a minor performs for his or her parents or guardians. Both prohibit minors from working if the activity is designated as hazardous.

106. Other member nations are Belgium, Denmark, France, Greece, Ireland, Italy, Luxembourg, the Netherlands, and Great Britain.

107. Vertrag zur Gründung der europäischeer Wirtschaftsgemeinschaft, March 25, 1957, and Gemeinschaftscharta der sozialen Grundrechte der Arbeitnehmer, December, 1989. See ZölLNer UND LoRITZ, supra note 23, at 114.

108. ZöllNer UND LORITz, supra note 23 , at 120 . In addition to the nationality of the employee, other relevant factors in determining the appropriate law are currency in which wages are paid, place of employment contract, and language of the employment contract. Id. at 121.

109. The applicable statute is Arbeitsforderungsgesetz (AFG) 19 abs. 1 Satz 1, 1969 BGB1. I S. 582.

110. 29 U.S.C. $203(1), 213(c)$ and (d) (1938).

111. Jugendarbeitsschutzgesetz (JASchG), 1976 BGB1. I S. 965. 
The German statute, however, contains some additional measures that should be noted by the American manager. German law explicitly encompasses within the idea of the "hazardous" work proscription for minors not only the physically hazardous prohibition in the FLSA, but also any activity deemed morally deleterious or injurious to his spiritual well-being. ${ }^{112}$ This is a somewhat nebulous concept which merits thoughtful reflection if workers under age 18 will be hired by a company doing business in Germany.

Also, the German statute augments many of the mandatory vacation and permissible work hour laws in effect for the adult worker. In particular, the 18-day paid annual vacation is increased for the working minor to 25-30 days, on a decreasing scale as he becomes older. ${ }^{113}$ The obligatory rest pauses also are increased to 30 minutes for $41 / 2$-hour to 6 -hour work segments, and to 60 minutes for work segments over six hours. ${ }^{114}$

Finally, German law contains elaborate provisions for the employer to require periodic physicians' certifications that the minor is able and fit to perform the duties of the job. ${ }^{115}$ Evidence of these examinations is required before the employment of a minor is lawful, but costs are borne by the Land government rather than the employer. ${ }^{116}$

\section{The Disabled Worker}

The statutes providing protection for disabled workers, The Americans with Disabilities $A c t^{117}$ and the Schwerbehindertengesetz, ${ }^{118}$ are radically dissimilar. Only the most fundamental sections will be mentioned, ${ }^{119}$ but a company transacting business in either country should be thoroughly familiar with the applicable law outlining duties to employees with disabilities.

112. Id. $\$ 22$ abs. 1(2) (exceptions are created for apprenticeships and where the minor has a direct supervisor).

113. Id. $\ 19$.

114. Id. 11. Compare with the usual 30-minute break after six hours work. See supra note 68 and accompanying text.

115. JASchG \$32 et seq. This section applies only for work that is to last more than two months. Id.

116. Id. $\$ 44$.

117. Americans with Disabilities Act of 1990, Pub. L. No. 101-336, 104 Stat. 327 (codified as amended in 29 U.S.C. $\$ 706,42$ U.S.C. $\$ 12101-12213,47$ U.S.C. of $152,221,225,661$ ) [hereinafter ADA].

118. Erstes Gesetz zur Änderung des Schwerbehindertengesetzes (SchwbG), 1989 BGB1. I S. 1110, und Gesetz zur Sicherung der Eingliederung Schwerbehindertes in Arbeit, Beruf und Gesellschaft (SchwbG), 1986 BGB1. I S. 1421, ber. 5.1550.

119. For a detailed comparison, see Carol D. Rasnic, A Comparative Analysis of Federal Statules for the Disabled Worker in the Federal Republic of Germany and the United States, 9 ARIz. J. OF INT'L. ANd Comp. L. 283 (1992). 


\section{United States}

The definition of a disabled person entitled to protection-any "qualified person with a disability" - is a three-part alternate one. One is disabled if he or she either (l) has a physical or mental impairment that substantially limits one or more major life activities, (2) has a record of such impairment, or (3) is regarded as having such an impairment. ${ }^{120}$

An employer must comply with the ADA if it has 25 or more employees. ${ }^{121}$ The company's duties under the law are to the individual disabled applicant or employee, and the statute does not refer to disabled persons as a group or entity. "Reasonable accommodations" must be made in the work place for a qualified person with a disability, ${ }^{122}$ but the employer's obligations are limited insofar as it need not undergo an "undue hardship" to make such an accommodation. ${ }^{123}$ Also, the worker is not entitled to the protection of the law if the employer can show that he or she poses a "direct threat"' to others' safety or health. ${ }^{124}$

Violations can be quite costly for the noncomplying business. Not only can a plaintiff obtain injunctive relief, including hire, reinstatement, and/or back wages, but he is also entitled to a jury's award of compensatory and punitive damages in maximum amounts ranging from $\$ 50,000$ to $\$ 300,000$, according to the defendant's total number of employees. ${ }^{125}$

\section{Germany}

The Schwerbehindertengesetz expands for the disabled worker many of the statutory rights granted all workers. One such right is the required

120. ADA, supra note $117, \$ 3(2)$. The same Health, Education and Welfare (HEW) regulations which apply to the Rehabilitation Act, 29 U.S.C. $\$ 706(8)(B)$ (Supp. 1990) set the standard for "major life activities" in the ADA. These include "caring for one's self, performing manual tasks, walking, seeing, hearing, speaking, breathing, learning, working and participating in community activities." H.R. Rep. No. 485, 101 st Cong., 2d Sess., pt. 2, at 52 (1990), reprinted in 1990 U.S.C.C.A.N. 334.

121. ADA, supra note $117, \$ 101(5)(\mathrm{A})$. The employee count will decrease to 15 or more on July $26,1994$.

122. Id. $101(9)$.

123. Id. $\$ 101(9),(10)$.

124. Id. $\$ 102(4)$.

125. ADA, 107 (a). Section 107(a) expressly incorporates the remedies provided by Title VII of the Civil Rights Act of 1964, as amended in 1991. These amended sections are in 42 U.S.C. SS $2000 \mathrm{e}-4 \cdot 2000 \mathrm{e}-9$ (1991). 
notice before termination. Although the employer usually can choose either the 2-week notice before termination required by statute for bluecollar workers or the 6-week notice required under the white-collar law for all employees, ${ }^{126}$ the law assures the disabled worker no less than four weeks' notice. ${ }^{127}$ This 4-week provision applies, even if the particular employer as a rule adheres to the 2-week notice option.

For termination of a disabled person, the employer must notify not only the works council (Betriebsrat), as it must with respect to all employees, but it also must notify the welfare office (Hauptfürsorgestelle). This office then has four weeks within which to convey its position to the employer, ${ }^{128}$ so the implementation of the intended termination is prolonged. Secondly, the disabled worker is entitled to five paid vacation days per year ${ }^{129}$ in addition to the 18 days guaranteed for all workers. ${ }^{130}$

Under the German statute, a disabled person (Schwerbehinderte) is any one with a $50 \%$ or more reduced capacity to function in the daily activities of his life. ${ }^{131}$ Official evidence of disability is a certificate (Ausweis) which is issued by a federal pension office, provided that office is satisfied that he has the requisite $50 \%$ limitation. ${ }^{132}$

All businesses with 16 or more work positions (Arbeitsplätze), whether or not such positions are currently filled, are covered by the law. ${ }^{133}$ Employers subject to the Schwerbehindergesetz are required to meet a quota: $6 \%$ of the Arbeitsplätze are to be filled with disabled persons. The German business which has not complied with the $6 \%$ rule simply pays a monthly assessment of DM 200 for each Arbeitsplatz not filled by one with a disability. ${ }^{134}$ The statute also provides opportunities for employers to obtain credit toward their quota obligation if they hire 1990.

126. BVerfG, Entscheidung 82 S. $126=$ AP Nr. 28 zu $\ 622$ BGB, May 30 ,

127. SchwbG 16. See supra notes $94-97$ and accompanying text.

128. Id. $\subseteq 18$ abs. 1. Cf. with the 1-week response time for the Betriebsrat (works council) to the employer. BetrVG $\$ 102$.

129. SchwbG \47.

130. See BUrlG $\$ 3$ abs. 1 .

131. SchwbG $\$ 1$.

132. Id. $\$ 4$ abs. 1 .

133. Id. $\$ 5$.

134. Id. 11 abs. 2. This payment is referred to as an "Ausgleichsabgabe," or "payment to equalize duties." This infers that an employer which has not followed the statutory directive has met his burden through an alternate method, one which has not benefitted the disabled as an individual. 
persons with special disabilities, ${ }^{135}$ or if they participate in the statutory program for workshops ("Werkstätten") designed to rehabilitate and train disabled persons to learn a vocation. ${ }^{136}$

This summary reveals quite basic differences as to which persons are to be protected, the obligations imposed on covered businesses, and the consequences of noncompliance. The conscientious American employer has struggled to become knowledgeable of the substantive provisions in the new ADA, and the German business is accustomed to the quota method effected through the Schwerbehindertengesetz. Both must become familiar with an entirely antithetical statute if the decision is made to relocate operations.

\section{The Female Worker}

\section{United States}

The two primary laws in the United States designed to better working conditions for women are the 1963 Equal Pay Act ${ }^{137}$ and Title VII of the 1964 Civil Rights Act, most recently substantially amended in 1991. ${ }^{138}$ The Equal Pay Act requires equal pay for equal work between the sexes, such "equality" of work being measured by four cumulative criteria: (1) skill, (2) effort, (3) responsibility, and (4) working conditions. A defending employer might justify pay disparity between male and female workers performing equal work if it were based on any one of four affirmative defenses: (l) quality or quantity of work, (2) seniority, (3) merit, or (4) a factor other than sex. ${ }^{139}$ Although the law is written in gender-neutral language, the Congress' purpose is generally accepted as having been to close the significant gap in compensation heavily favoring male workers. ${ }^{140}$

Title VII proscribes any differential treatment based on the employee's race, color, sex, religion, or national origin. Prohibited discrimination not only relates to compensation, but also to any "terms, conditions, or privileges of employment." ${ }^{141}$ The main defense for an

135. SchwbG $\ 10$.

136. Id. $\$$ 54-58.

137. Equal Pay Act of 1963, Pub. L. No. 88-38, 77 Stat. 56 (codified as amended at 29 U.S.C. $\$ 206(d)(1988)$.

138. Civil Rights Act of 1964, 42 U.S.C. 2000e-2000h (1988) (199l).

139. 29 U.S.C. $\$ 206(d)$ (1988).

140. See David P. Twomey, Labor Law and Legislation 445 (7th ed. 1985).

141. 42 U.S.C. $\$$ 2000e-2(a) (1988). 
employer's intentional exclusion of one sex from any work position is proof that gender is a bona fide occupational qualification (BFOQ) ${ }^{142}$ One of the most oft-cited successful uses of this defense in sex discrimination litigation was in Dothard v. Rawlinson ${ }^{143}$ where the U.S. Supreme Court accepted the position of the defending Alabama state prison system that guards in an all-male maximum security facility must be men. Holding the essence of the job, or the "normal operations of the business," to be the maintenance of prison security, ${ }^{144}$ the Court reasoned that the presence of a woman on the staff of such an institution would result in likely riots and violence. ${ }^{145}$

The Court has routinely applied the defense quite strictly, ${ }^{146}$ however, and no decision indicates this more emphatically than does $U A W$ v. Johnson Controls. ${ }^{147}$ A unanimous Court in Johnson Controls struck down the defendant company's policy prohibiting any woman with childbearing capacities from working in jobs exposing her to lead-containing batteries, likely to be harmful to an unborn fetus. Pivotal in the decision $^{148}$ was the Pregnancy Discrimination Act amending Title VII, ${ }^{149}$ which expressly prohibits discrimination because of pregnancy, childbirth, or related medical conditions. The Court viewed the "normal operation of the business" simply to be the making of batteries, ${ }^{150}$ irrespective of whether a fetus was at risk, and thus did not accept the $B F O Q$ defense.

The significance of Johnson Controls is twofold: it demonstrates both (1) the Court's narrow application of the BFOQ in sex discrimination cases; and (2) the near-absolute right of the female to be free from

142. Title VII permits discrimination based on sex, religion or national origin if the discrimination is a "bona fide occupational qualification reasonably necessary to the normal operations of that particular business or enterprise." 42 U.S.C. $\$ 2000 \mathrm{e}$ 2(e)(1) (1988).

143. 433 U.S. 321 (1977).

144. Id. at 335 .

145. The inadequacy of staffing and facilities had created what the Court acknowledged to be a "jungle atmosphere," in which a woman staff member would invite assaults by the large percentage of sex offenders long deprived of -normal heterosexual relationships. Id. at 334-36.

146. See Dothard, 433 U.S. 332-37.

147. 111 S.Ct. 1196 (1991).

148. Id. at $1203, \mathrm{n} .3$.

149. The Pregnancy Discrimination Act, $\$ 701(\mathrm{k})$ of Title VII, was added to the law in 1978. This amendment was Congress' response to an earlier holding by the Court in Gilbert v. G.E., 429 U.S. 125 (1976), that discrimination by reason of sex did not include discrimination by reason of the employee's pregnancy.

150. $111 \mathrm{~S}$. Ct. at 1206 . 
work place discrimination, provided only that there be no adverse effect on her, the performance of the operation, or the employer's business or facility.

\section{Germany}

Contrary to the anti-discrimination laws of the United States, German statutory law actually mandates differential treatment for the female worker, albeit those presumably beneficial for her.

First is the law applicable to the pregnant worker and the mother, expressly requiring what the Pregnancy Discrimination Act prohibits. The Law for the Protection of Working Mothers (Mutterschutzgesetz) ${ }^{151}$ assures special treatment both during pregnancy and during the time a working mother is nursing her child. It contains a litany of jobs based upon the degree of physical effort required which are prohibited for such workers. ${ }^{152}$

The pregnant woman is generally precluded from working during the six weeks preceding the projected birth of the child and for eight weeks afterward..$^{153}$ Overtime work is forbidden for the nursing mother, ${ }^{154}$ and she is entitled to time off with pay to nurse the child, should she return to work during the time she is doing so. ${ }^{155}$ The federal government provides for payment to the working mother of DM 25 per day during this mandatory time off, ${ }^{156}$ and the employer is liable for any difference between this amount and her average pay. ${ }^{157}$ Further, her job must be held for her for at least four months after the birth of the child. ${ }^{158}$

The working woman in general is provided privileges beyond those of her male counterpart. Although the male blue-collar worker must be given a break after six hours of work, the female is guaranteed a 20-minute break after only four and one-half hours of work. ${ }^{159}$ The

151. Mutterschutzgesetz (MuSchG), 1968 BGBl. I S. 315.

152. MuSchG 4(2), and Arbeitsstoffverordnung (ArbStoffV) $\$ 14(4)$.

153. MuSchG $3(2)$ and $6(1)$. This post-birth hiatus is 12 weeks for premature and/or multiple births.

154. Id. $\$ 8$.

155. Id. 7 .

156. MuSchG $\{14$ and Reichsversicherungsordnung (RVO) S 200(1)-200(3). The payment to the mother but not to the father probably reflects the primary concern of the Bundestag as being the health of both mother and child, rather than the time the parent might spend with the new baby.

157. MuSchG of 11 and 14.

158. Id. $\$ 9$.

159. AZO $\$ 18$. 
blue-collar female worker cannot work prior to $6 \mathrm{a} . \mathrm{m}$. nor later than 8 p.m., and she cannot work later than 5 p.m. on a day preceding a Sunday or legal holiday. ${ }^{160}$ The male worker has fairly liberal choices regarding overtime work, but the female worker is prohibited from working more than ten hours per day. ${ }^{161}$ Finally, women are strictly forbidden to work in mines, in the iron and steel industries, in coke plants, and on most construction site jobs. ${ }^{162}$

The American employer which has conditioned its management decisions carefully to avoid any distinctions between the male and female worker must assume a completely different posture in the German work place. It is apparent that the German working woman is assured many privileges which would be patently unlawful in the United States. ${ }^{163}$

\section{Conclusion}

It is logically foreseeable that cross-continental investments by businesses in Germany and the United States will continue to increase. Efforts to avoid the relative monetary burdens imposed on German companies in their home situs induces them to seek a more financially advantageous location, and the United States has been referred to as the "favorite investment land for Germans." 164 American concerns also will be attracted during the next several years to newly available opportunities in the former DDR. Such purchases can be quite desirable from the perspective of price and initial required costs.

That the essential utilitarian goal of the business enterprise is the production of income and maximization of profits is a truism. To a degree, tax liabilities, licensing fees, and potential financial burdens associated with purchasing materials and equipment are fixed costs which even entrepreneurial ingenuity cannot alter. A more variable

160. Id. $\$ 19(1)$.

161. Id. $\$ 17$.

162. See generally Carol D. Rasnic, Germany's Legal Protection for Women Workers vis-a-vis Illegal Employment Discrimination in the U.S., 13 Мrсн. J. OF INT'L. L. 415, n. 22-25 (1992).

163. There are some in Germany who share the view of supporters of women's rights in the United States that these "privileges" are in fact hindrances. For example, a nationally televised news commentary recently reported a groundswell of discontent and frustration among women in Germany because of the perceived causal connection between these laws and their inability to acquire or retain full time jobs. Such pressure and hardship is particularly difficult in the former DDR, where overall unemployment has reached a critical level. Bonn Direct (Broadcast, February 21, 1993).

164. Treumann et Al., supra note 1 , at 9 . 
factor derives from costs of the employment relationship, at least to the extent that wages, salaries and benefits might be negotiated. This element of the investment decision is thus most significant, so the latitude permitted management with respect to its treatment of labor should be closely studied before the commitment is finalized. ${ }^{165}$

These cautionary remarks are not designed to deter transnational investments by German or American businesses. In particular, the American company should not be completely dissuaded by the "doomand-gloom" forecasters insisting that western German labor is unwilling to assume its share in the reunification burden. This contingent does not envision their sacrificing 40 years of progressively uninterrupted higher wages, shorter hours, longer vacations, and more holidays and sick leave. This view portends much prolonged labor turmoil for Germany. ${ }^{166}$ Other esteemed prognosticators, however, are confident that reunification will pose no insurmountable labor strife in the near future, since the average German "knows how to work" and will agree to work longer hours to prevent having to reduce his enviable standard of living. ${ }^{167}$

The message is simply one urging reflection in a critical area where German and American laws are notably disparate. The thorough business investor should assess the labor and employment laws of the new situs and look long before it makes the proverbial leap.

165. Because there is a paucity of cross-referenced German and U.S. material on labor and employment law, there may be a tendency to downplay its import in business decisions. For example, Treumann ET AL., supra note 1, is an excellent resource, both for the German and U.S. business investing in properties in the other country. However, although it provides exhaustive treatment of the differences in the respective laws regarding taxation, forms of business organization, antitrust, intellectual property, and banking, its chapter on labor and employment is surprisingly meager. The 21 pages of this chapter make it the shortest in this otherwise valuable and informative investment guide, and the authors appear to have discounted the significance of these laws for the international business.

166. Dornberg, supra note 64.

167. Lothar Löwen, German news correspondent, addressing Fulbright Commission seminar, March 27, 1993, Berlin. 
